\title{
Article \\ Empowering Workers and Learners through a Combined Participatory Action Research and Research Justice Approach
}

\author{
Sophia L. Ángeles ${ }^{1,2, * \mathbb{D}}$, Michele J. Wong ${ }^{1,2} \mathbb{D}$, Janna Shadduck-Hernández ${ }^{1,2}$ and Preeti Sharma ${ }^{3}$ \\ 1 UCLA Labor Center, University of California, Los Angeles, CA 90057, USA; mwongj09@g.ucla.edu (M.J.W.); \\ jshernandez@irle.ucla.edu (J.S.-H.) \\ 2 UCLA Institute for Research on Labor and Employment, University of California, \\ Los Angeles, CA 90057, USA \\ 3 Department of American Studies, California State University, Long Beach, CA 90840, USA; \\ preeti.sharma@csulb.edu \\ * Correspondence: slangeles@g.ucla.edu
}

check for

updates

Citation: Ángeles, Sophia L., Michele J. Wong, Janna Shadduck-Hernández, and Preeti Sharma. 2022.

Empowering Workers and Learners through a Combined Participatory Action Research and Research Justice Approach. Social Sciences 11: 60. https://doi.org/10.3390/socsci 11020060

Academic Editors: Steven McKay and Claudia Lopez

Received: 16 December 2021

Accepted: 30 January 2022

Published: 8 February 2022

Publisher's Note: MDPI stays neutral with regard to jurisdictional claims in published maps and institutional affiliations.

Copyright: (C) 2022 by the authors. Licensee MDPI, Basel, Switzerland. This article is an open access article distributed under the terms and conditions of the Creative Commons Attribution (CC BY) license (https:// creativecommons.org/licenses/by/ $4.0 /)$.

\begin{abstract}
The UCLA Labor Center used a combined participatory action research and research justice approach to study the challenges faced by workers and learners. Workers and learners are students who work while studying throughout their college careers. This research project has been carried out with the assistance of undergraduate students and college partners. We outline in detail the process we undertook to involve more than 500 students, beginning with the study design and ending with the dissemination of study results. We discuss the ways in which we, as researchers, were able to intentionally engage participants and honor their knowledge throughout the research process in order to advance policy reforms. This work entails of incorporating tenets of participatory action research (PAR) and Research Justice (RJ) to build the capacity of partners to produce knowledge. To this end, the work involves participants in every step of the knowledge lifecycle so that research across varying disciplines can impact education and employment policies that improve conditions for workers and learners in workplaces and universities and colleges.
\end{abstract}

Keywords: research justice; participatory action research; community partnerships; undergraduate students; labor studies

\section{Introduction}

For decades, more working-class students have gained access to college. Those attending public colleges and universities often do so without the financial security of low college tuition and financial support from which older generations benefitted (Perna and Li 2006). To counteract the divestment in public institutions of higher education, and, consequently, in students, a growing number of college students have sought employment, adding to the growing population of workers and learners on college campuses. As a population who work and study simultaneously throughout the school year, workers and learners face unique challenges in their day-to-day lives, such as lack of access to flexible work schedules (Shadduck-Hernández et al. 2018) or academic support (Blanchard Kyte 2017). Their unique struggles as workers and learners have become an issue of justice. Yet very few studies have examined the experiences of workers and learners (Broton et al. 2016; Riggert et al. 2006), much less how their jobs affect their schooling and vice versa (Allison et al. 2015; Cammarota and Fine 2008; Dwyer 1977). Scholarship that examines the experiences of working students tends to highlight the effects of work on their academic performance and career trajectories, paying little to no attention to how working students navigate both school and work. To address this pressing social problem and empirical gap, the Workers and Learners project, which spanned more than two years, examined the experiences of workers and learners attending three California public college systems in Los Angeles County. 
As a community-engaged scholarship, the Workers and Learners research project not only seeks to identify the structural causes that result in a growing number of workers and learners on college campuses, but also engages undergraduate students in the research process, of whom the majority are workers and learners. Our research inquiry is informed by the epistemologies of participatory action research (PAR) and Research Justice (RJ), as indicated in our research and the course design that shaped the Workers and Learners project. To examine workers and learners' experiences as they manage their work and school responsibilities, our research project reflects the long lineage of research rooted in PAR that examines issues of inequity alongside those most affected (Dick 2015; Torre et al. 2012; Zeller-Berckman 2014). Whereas most recent PAR projects have committed to being participatory by involving K-12 students (Bertrand 2018; Cammarota and Fine 2008; Torre and Fine 2006) or specific industries like domestic workers (Burnham and Theodore 2012) or food workers (The Food Chain Workers Alliance 2012) in the research process, the Workers and Learners project exemplifies the possibilities that emerge when scholars couple PAR with RJ to study issues that lie at the intersection of education and labor.

The larger goal of the Workers and Learners project is to examine the experiences of workers and learners through a labor lens, thus allowing us to see students as workers who are simultaneously navigating the challenges of working and being a student (see Ángeles et al. 2020, 2020, for a discussion of findings). However, this article focuses on the mechanisms we created to intentionally include and allow for the full participation of workers and learners throughout the research process, which is consistent with the core components of more critical community-engaged scholarship (e.g., real-life social problems are defined, investigated, and addressed with or by the community; Gordon da Cruz 2017). Additionally, by sharing the Workers and Learners project research process informed by PAR and RJ this article seeks to help other researchers and practitioners more critically engage in community research.

\section{Literature Review}

Since the 1970s, public higher education institutions have been targets of budget cuts and accountability efforts in order to more efficiently produce college graduates. With ever-shrinking budgets, the state's investment in public education has been declining, causing state schools to increase their tuition and fees. At the national level, student aid has not kept pace with the ever-increasing cost of a college education in the 21st century. This combination of factors has created the student debt crisis, which affects a range of students, particularly those who have been historically excluded from postsecondary institutions, often first-generation college students. Given the increasing need for individuals to seek postsecondary education and preparation to succeed in a fast-changing, global, and highly technological economy, students have come to rely on more precarious, low-wage, and unsustainable jobs to manage their unmet financial needs (Ángeles et al. 2020a; Carnevale et al. 2015; Carnevale and Smith 2018).

Working to supplement financial aid is not a new strategy. In fact, decades ago, such efforts were common among college students. Many students who worked part-time jobs or summer jobs saved enough money to pay their tuition and living expenses without much distress. Today, though, such arrangements are no longer plausible, especially in urban areas like Los Angeles County, which has a high cost of living index (Manzo et al. 2021). Workers and learners, whom we refer to as people enrolled full-time in school and working at least $16 \mathrm{~h}$ a week, are a growing population of students across college campuses. Because a large portion of workers and learners tend to also identify as a first-generation college student, a student of color, and/or a student from a lower socioeconomic background, universities and employers must consider the ways in which they are supporting their academic and professional aspirations. These students not only make up part of our future workforce, but also represent the new traditional college student.

Though our understanding of the role of work in college students' lives is growing (Ángeles et al. 2020; Blanchard Kyte 2017; Carnevale and Smith 2018), we still know very 
little about how labor practices impact college students and how these practices intersect with academic ones and thus shape a worker and learner's day-to-day experience. Scholars from across a number of disciplines have found that people who are both enrolled full-time in school and employed for at least $16 \mathrm{~h}$ per week tend to face several challenges, the most concerning of which is delayed graduation times and/or deferral of studies (Carnevale and Smith 2018; Horn and Malizio 1996). Graduation times are also affected by the unstable schedules many workers and learners face (Ben-Ishai et al. 2016), which compel many such students to decide whether to prioritize school over work or vice versa (Ángeles et al. 2020; Shadduck-Hernández et al. 2018). Despite workers and learners' desire to use their earnings to cover college expenses, many working in low-wage positions in the service industry find themselves unable to meet the rising costs of education (Carnevale and Smith 2018). Lack of accommodations and inflexible managers or faculty members can be another source of concern (Ben-Ishai et al. 2016), in part because most workers and learners are not unionized, especially as student campus workers (Flaherty 2019; Jacobs and Thomason 2018). Despite countless hours and multiple jobs, many individuals in this population remain housing and food insecure and worry about the affordability of future college semesters (Broton and Goldrick-Rab 2018; Crutchfield et al. 2016; Raskind et al. 2019).

The needs and struggles of workers and learners are invisible to many of their peers and colleagues with whom they interact on a daily basis at school and work. Though they are both workers and learners, they are often seen solely as a learner on the college campus, and a worker at their place of employment. In reality, they are both (Sukarieh and Tannock 2015). Policymakers, educators, and employers must offer solutions to the dire situations confronting workers and learners by empowering them in their dual roles.

\section{The Specific Study Context}

The UCLA Labor Center's Workers and Learners project builds upon research conducted in 2014-2015 with young workers. This project involved not only collecting survey and interview data but also creating a short film, photo project, and curriculum to engage audiences around the study (for more details, see Sharma et al. 2020). The I am a \#Young Worker study focused on the experiences of young adults (ages 18-29) working in the service industry in Los Angeles County, in which we found that over a third of young workers were also attending college (Waheed et al. 2015). Despite working, many young workers in school had accumulated an average of USD 20,000 in debt (Waheed et al. 2015). Such findings led us to examine the experiences and challenges of students who work across Los Angeles County as they navigate multiple public educational institutions and work across several job sectors.

Studying the experiences of workers and learners in Los Angeles is important for a number of reasons. Students-from those in high school to those in graduate programsare integral to the fabric of Los Angeles County, comprising 2.7 million people and over one-quarter of the total population in 2018. Among all learners, $27 \%$ were in undergraduate programs, and the majority (82\%) attended public colleges and universities. Among all students in Los Angeles County, $18 \%$ were employed, but $52 \%$ of undergraduates were working. In 2018, the research team began to work with multiple college partners across Los Angeles County to train students in field surveying for the Workers and Learners research project. In what follows, we outline our use of RJ and PAR as theoretical frameworks and the ways in which we integrated students, many of whom were workers and learners, over the course of the research process.

\section{Conceptual Framework: Coupling Participatory Action Research with Research Justice}

The history of PAR spans decades and includes various continents around the world. In the United States, scholars like Kurt Lewin and W. E. B. DuBois were among the first to utilize features of PAR to conduct investigations that examine "the policies, institutions, and social arrangements that help to form and deform, enrich and limit, human development" 
(Torre et al. 2012, p. 179). As a research methodology, PAR focuses on being inclusive of communities as researchers who investigate social problems. Among the first to utilize Action Research in the United States, Lewin saw the process as a "means of systematic enquiry for all participants in the quest for greater effectiveness through democratic participation" (Adelman 1993, p. 7). Scholars of PAR also believe that documenting and examining the structures that create social injustices is necessary for informing and transforming policy and practices (Zeller-Berckman 2014).

The "participatory" element of PAR reflects its close consideration of participants' role in research (Kindon et al. 2007). Scholar Michelle Fine has written about how the addition of the word "participatory" was meant to signal a shift in the ways that researchers were approaching action research and interacting with participants. This new task opened up opportunities for researchers to invite participants who were more intimately aware and directly affected by the issue under investigation. Including them in the research allowed participants to "shape the questions, the research, the knowledge, and the products" (What Kids Can Do n.d.). This method shifted how researchers viewed their participants, transforming them from subjects and even objects into advisors and experts (What Kids Can Do n.d.). With this model, researchers would no longer carry out studies on their own, but in partnership with those directly affected by the issues being studied. In Latin America, scholar Fals Borda has envisioned the researcher as someone who "facilitated the transformation of common knowledge to critical knowledge within a research collective" (Zeller-Berckman 2014, p. 6). For Fals Borda, this effort meant working directly with Colombian peasant-farmers organizing to secure agrarian reform (Gutiérrez 2016; Robles Lomeli and Rappaport 2018). In recent years, scholars such as Torre et al. (2012) have discussed critical PAR as an epistemology rooted in "democratic participation" (p. 171). Working alongside study participants, critical PAR scholars tend to "operate on the more participatory end of the spectrum" (Zeller-Berckman 2014, p. 17).

At the UCLA Labor Center, our commitment to including participants throughout the research process is also informed by a research justice framework (Data Center: Research for Justice 2013; Jolivétte 2015). Operating within this framework means that research is utilized as a "vehicle for community to reclaim, own and wield all forms of knowledge and information as political ammunition in their own hands, in ways that are consistent with the community's unique cultural and spiritual identity, and values and traditions" (Kim Lee 2015, p. xviii). The inclusion of students, many of whom identify as workers and learners, demonstrates our commitment to "expand[ing] traditional views of expertise, recognizing situated knowledge and systemic relationships" (Torre et al. 2012, p. 181). Research Justice scholars importantly describe intentional participant involvement as necessary for researchers to address the "limit[s] of community-based research," as it "move[s] beyond participation to 'community driven' research, which prioritizes self-determination and community power" (Oparah et al. 2015, p. 121). Having students at the research table allows the research team to directly factor in and gain better insight into the subjective experiences they and their peers undergo as well as shape the research design. From the outset of our research design, we saw the students-who represent diverse worker and college experiences and communities across Los Angeles County-as experts who can comment on and contribute to all aspects of the research. Our critical engagement with them and their diverse knowledge sets and resources also collectively shaped the study's policy and social reform recommendations and action agendas (Jolivétte 2015). Privileging the expertise of workers and learners allows us to move towards attaining not just research justice, but social justice (Gordon da Cruz 2017). How we intentionally carried out this project with students as fellow researchers throughout all aspects of the inquiry process is the focus of our paper.

\section{Methodology}

The University of California, Los Angeles (UCLA) Labor Center and the Dolores Huerta Labor Institute of the Los Angeles Community College District, in partnership 
with the UCLA Institute for Research and Employment and the UCLA Labor Studies program, launched the Workers and Learners research project to contextualize the realities of this population and build broader engagement among community, educator, employer, and policy stakeholders in 2017. This multi-year project continues as we explore the ramifications of COVID-19 on workers and learners' academic and work experiences (Ángeles et al. 2020b; Labor Summer Research Program 2020 Team 2020).

To date, we have carried out three different studies: Unseen Costs: The Experiences of Workers and Learners in Los Angeles County (Ángeles et al. 2020b); A Survey of Workers and Learners in Los Angeles County During COVID-19 (Ángeles et al. 2020a); Workers and Learners during a Global Pandemic and Social Uprising (Labor Summer Research Program 2020 Team 2020). We used surveys and interviews across our three studies to better understand the experiences and challenges of students who work. For our larger project, Unseen Costs, we collected 869 surveys and 75 interviews across the public university system in Los Angeles County between August 2018 and May 2019 (Ángeles et al. 2020b). In response to the COVID-19 pandemic, we surveyed 236 workers and learners attending public colleges in Los Angeles County (Ángeles et al. 2020a). Our most recent report is based on 138 surveys and 25 interviews collected from Los Angeles public colleges and universities in August 2020. This most recent study builds on existing knowledge concerning the experiences of workers and learners by documenting how their academic, employment, and life experiences have changed since the onset of the COVID-19 pandemic in a moment of social uprising (Labor Summer Research Program 2020 Team 2020).

Unique to this project is how our research team has worked with California Community College, California State University, and UCLA professors and students to implement the survey and participate in the data analysis. Since 2018, we have recruited more than 500 students through their college classes to participate in the research process. We trained students to conduct face-to-face surveys with workers and learners within their community and peer networks. The surveys touched upon their education/college experiences, work experiences, the impact of "doing" both education and work, and demographics, as well as the impact of COVID-19 and Black Lives Matter protests. An additional core team of 50 undergraduate students developed interview guides and engaged in data analysis through independent study and the UCLA Labor Summer Research Program (LSRP) over three summers. These smaller groups of undergraduate students delved deeper into issues affecting workers and learners such as the toll that working and learning takes on their mental health and their sense of belonging. Participants received a USD 20 stipend for completing a survey, and a USD 25 e-gift card (LSRP 2018 and LSRIP 2020) or a water bottle (LSRP 2019) for the interview.

We sought to include students in a participatory research process that prioritizes student-worker leadership and centers workers and learners' perspectives. Our approach included developing survey and interview questions with a group of workers and learners. Collecting and analyzing data was integrated as a class assignment across community college and university courses in the California Community College, California State University, and University of California institutions in Los Angeles County. We utilized a combination of both small and large group activities to review and discuss the implications of the research findings. In addition, a core undergraduate research team led deeper analysis to synthesize the results through a series of UCLA Labor Studies courses (see Table 1). Together with students, we developed data infographics and disseminated the findings to other workers and learners and community stakeholders through a series of in-person workshops and online-webinars. 
Table 1. Timeline of Research Process.

Timeline of Workers and Learners Research Project

\begin{tabular}{|c|c|c|}
\hline Duration of Research Phase & Research Phase & Specific Activities \\
\hline & & $\begin{array}{l}\text { UCLA undergraduate students and the research team developed } \\
\text { a literature review. }\end{array}$ \\
\hline $\begin{array}{l}\text { Academic Year } \\
\text { 2016-2018 }\end{array}$ & $\begin{array}{l}\text { Research design with } \\
\text { workers and learners }\end{array}$ & $\begin{array}{l}\text { UCLA undergraduate students engaged in discussions about the } \\
\text { experiences of students who work throughout college with } \\
\text { community stakeholders and experts. }\end{array}$ \\
\hline
\end{tabular}

UCLA undergraduate students and the research team developed research questions for the survey and interview.

UCLA undergraduate students in the 2018 Summer LSRP piloted and refined the survey.

UCLA undergraduate students and research team visited Study 1 Data Collection community college and university classes to introduce Workers and Learners project and trained them in survey data collection. California Community College, California State University, and UCLA students collectively engaged in gathering survey and interview data.

Academic Year 2018-2019

Data analysis with workers and learners
As survey and interview data were collected, UCLA undergraduate students and the research team re-visited community college and university classes to analyze emerging findings together. This was an ongoing process that lasted months.

Once the data collected were cleaned, UCLA undergraduate students in the 2019 Summer LSRP began to analyze 869 surveys.

UCLA undergraduate students in the 2019 Summer LSRP program collected 30 more interviews to gather more specific data $(\mathrm{n}=75)$.

Academic Yea

Continuation of Study 1

Data Collection

Data analysis with workers

A group of UCLA undergraduate students analyzed interview data $(n=75)$ and engaged in writing memos.

and learners

Study 2 and 3 Data collection in response to COVID-19 and remote learning.

In the spring and summer 2020, the research team trained students attending Los Angeles Pierce Community College, California State University, Long Beach, and UCLA to collect survey and interview data. Data were analyzed together.

Academic Year 2020-2021

Dissemination with workers and learners
During the summer, workers and learners from the California Community College, California State University, and UCLA received training to be spokespeople and presented data to community stakeholders.

Workers and learners have since engaged in disseminating findings via blogs and online webinars.

\section{Creating Opportunities for Participation throughout the Knowledge Lifecycle \\ 6.1. Research Design with Workers and Learners}

Our commitment to research justice allowed us to reimagine the research design process. One of the primary tenets of RJ entails "traditionally marginalized communities identif[ying] a need for knowledge that can [then] be used as a basis for building power and creating institutional change" (Oparah et al. 2015, p. 121). For the Workers' and Learners' project, the research process begins with community members-or workers and learners, in our case- developing research questions and informing the research design process from the very beginning (Fine and Torre 2019; Gordon da Cruz 2017). Our research project began with the inclusion of undergraduate students who worked to shed light on the struggles they were facing as workers in their low-wage jobs, and the pressures to perform well as college students. 
Our first step in the research design process took place during the 2016-2017 academic year and involved a group of undergraduate students familiarizing themselves with the literature on student workers, working students, and their experiences of juggling work and school schedules (Blanchard Kyte 2017; Bozick 2007; Carnevale et al. 2015; Ehrenberg and Sherman 1987; Horn and Malizio 1996; Tannock and Flocks 2003). These undergraduate students were formally enrolled in an independent study with Shadduck-Hernández (see Table 1). While earning credits for their labor studies minor, undergraduate students gained research experience. The next step in this process involved undergraduate students with the support of Shadduck-Hernández inviting experts like scholar Sara Blanchard Kyte to speak to students and to the larger education community on her research concerning working learners (Blanchard Kyte 2017). Engaging with experts and community stakeholders occurred during the 2017-2018 academic year-after the undergraduate students completed an extensive literature review on the issues affecting workers and learners. These two activities helped inform the research questions and the framing for the Workers and Learners research project.

We strived to move away from passive participation and create opportunities for undergraduate students, who often identified as workers and learners, to partake in the research study's decision-making process (Zeller-Berckman 2014). Including undergraduate students as research partners (Asad 2019) allowed the project's foundation to meaningfully address the most pressing issues facing workers and learners with research and policy recommendations that fit their needs. Integrating undergraduate students into the study afforded them the opportunity to influence the "research questions and outcomes" and, consequently, to "determin[e] what social, legal, economic, cultural, and/or political policies are needed" (Asad 2019, p. 4). By reviewing the literature and allowing them to reflect on their own lived experiences, we created spaces for undergraduate students to begin naming the unsustainable - and often invisible-realities of juggling work and school. Extending such opportunities to our undergraduate students was critical in our effort to showcase how research can inform the goal of activism, which is to "change the conditions of social life which maintain irrationality, injustice and incoherent and unsatisfying forms of existence" (McTaggart 1994, p. 333).

\subsection{Data Collection with Workers and Learners}

A core focus of PAR is the inclusion and democratic participation of community members in the research process (Torre et al. 2012). While PAR researchers have made strides to increase community participation at all stages of research (Kindon et al. 2007; Fine and Torre 2019), community engagement can still vary throughout the research process (Dick 2015; Gaffney 2008; McTaggart 1994; Wadsworth 1998; Zeller-Berckman 2014). Assumptions about who the research experts are, who wields knowledge, and ultimately who holds power in the data collection process, often determines the degree of community participation. Utilizing the RJ framework, participation from workers and learners at all stages of research remained a core value and priority for our project. Before we began data collection, we partnered with faculty members who taught at various Los Angeles County colleges and universities (see Table 2). They helped broker the relationship between our research team and undergraduate students both at and outside of UCLA by integrating the Workers and Learners research project into their courses. Collaborating with faculty allowed us to center the efforts on more than 500 undergraduate students, many of whom identified as workers and learners, throughout the data collection process (Data Center: Research for Justice 2013).

Partnering with faculty allowed us to expand our involvement with undergraduate students in the Workers and Learners project. We aimed to be cognizant of the unequal power relationships between researchers and participants that tend to exist in social science research, including in the surveying process. Thus, we had UCLA undergraduate students train other undergraduate students across campuses to conduct the survey themselves. The UCLA student trainers had been involved with the Worker and Learners project during the 
research design process and early piloting of the survey (see Table 1). This arrangement allowed us to share power with undergraduate students, who not only shaped the project but helped expand the scope of data collection in a way that centered their personal experiences as workers and learners.

Table 2. Research Partners.

\begin{tabular}{ll}
\hline College System in Los Angeles County & Institution of Faculty Partners \\
\hline & Los Angeles Harbor College \\
California Community College & Los Angeles Mission College \\
& Los Angeles Pierce College \\
& Los Angeles Southwest College \\
& Los Angeles Trade-Tech \\
\hline & CSU Dominguez Hill \\
California State University & CSU Los Angeles \\
& CSU Long Beach \\
& CSU Northridge \\
\hline University of California & University of California, Los Angeles \\
\hline
\end{tabular}

During this second phase of the research process, undergraduate students collaborated on survey data collection from all the Los Angeles County public colleges and universities. Student trainers traveled to our faculty partners' college campuses and led survey training in their college classes. Undergraduates, with the assistance of research team members, reviewed the survey instrument, engaged in face-to-face role play, examined Institutional Review Board guidelines, and discussed recruitment strategies. Reading through the survey together afforded students time to reflect on the different sections of the survey and types of survey questions. In addition to covering all the data collection logistics in the 75-to-95-min training session, student trainers introduced the RJ framework to other students. Many participants were hearing about RJ for the first time. Our goal from the beginning was to communicate that our Worker and Learner surveys were "created and conducted by and for those impacted by the issue," so that we can "use it as a tool for social change" (UCLA Labor Center 2019, slide 5; Data Center: Research for Justice 2013). Overall, these student-led trainings familiarized the workers and learners with the content and structure of the survey, serving to demystify the research process and allowing them to engage further and offer their own insights.

The student-led training enlisted more than 500 workers and learners across Los Angeles County, who were trained to administer surveys and collect the data needed to drive change in their communities. The student-led training sessions were important for a few reasons. The workers and learners not only took on the role as surveyors, but also received training to learn how to create their own knowledge, a key process in keeping with the Research Justice framework (Smith 2015). Conversations about the importance of RJ helped workers and learners see themselves as the experts, situating their knowledge and perspectives as the foundation for the project. To maintain the "rigor" of what is often perceived as "true" scientific research, more traditional PAR methods may involve consulting with community members only after the data have been collected by the researchers (Sandwick et al. 2018). Utilizing an RJ framework through the data collection process guarantees that workers and learners personally document and examine the structures creating inequities in their lives as students and workers (Bay 2019). Workers and learners from different schools and backgrounds critically examined the issues they faced and collectively imagined the solutions that would best meet their needs (Darder 2015). Regular post-training debriefs with the survey training team helped us incorporate the feedback from the students, improve the material, and make it more accessible and comprehensible for the workers and learners participating in our subsequent trainings. 


\subsection{Data Analysis with Workers and Learners}

The third phase of our research process involved discussing the study's findings with those collecting the data. For the larger study, this process lasted more than a year. For the complementary studies, this process lasted the length of the students' course term. From the moment data were entered into Qualtrics, the data management software we utilized for this project, we included undergraduate students in our analytical process. The students, who were directly affected by precarious labor conditions and the lack of institutional support from colleges, were able to convey the meaning they attributed to the emerging data. Grounded in RJ, workers and learners brought their "multiple forms of knowledge" to the research table as we analyzed the experiences of workers and learners across Los Angeles County (Oparah et al. 2015, p. 135). Our goal was to move away from traditional PAR projects in which participants have a limited role in the analytical process after having been involved in the study design and/or data collection (Tanabe et al. 2018). They contributed key analytical insights (Sandwick et al. 2018) that informed the findings discussed in our multiple reports.

Working with the same students who helped us collect the data, we adapted our student-led trainings to incorporate new activities that facilitated focused discussions around the survey and interview raw data. Activities differed based on the data being analyzed-quantitative (survey) or qualitative (interview) data. Because the Workers and Learners research project has been both multi-year and spanned the entire county, data analysis took place across the different labor studies classes and independent study courses for which participating students received college credit (see Table 3).

Table 3. Related Courses.

\begin{tabular}{|c|c|c|c|}
\hline $\begin{array}{l}\text { Research Opportunities for } \\
\text { Undergraduates }\end{array}$ & Brief Description and Goals & Duration & Number of Students \\
\hline $\begin{array}{c}\text { UCLA Labor Studies Independent } \\
\text { Studies }\end{array}$ & $\begin{array}{l}\text { Workers and learners helped with various aspects of } \\
\text { the research process, including the literature review, } \\
\text { data collection, and data analysis as well as data } \\
\text { dissemination. }\end{array}$ & $\begin{array}{l}\text { Fall } 2017 \\
\text { Winter } 2019 \\
\text { Spring } 2019 \\
\text { Fall } 2020 \\
\text { Winter } 2021\end{array}$ & 10 \\
\hline UCLA Research Seminar & $\begin{array}{l}\text { In this course, students had an opportunity to analyze } \\
\text { data, contribute their analysis to the report, and create } \\
\text { recommendations and dissemination materials. } \\
\text { Students developed an understanding of the critical } \\
\text { debates regarding the role of research and policy as it } \\
\text { relates to Los Angeles's working students. }\end{array}$ & $\begin{array}{l}\text { Fall } 2018 \\
\text { Fall } 2019 \\
\text { Spring } 2020\end{array}$ & 22 \\
\hline $\begin{array}{c}\text { UCLA Labor Summer Research } \\
\text { Program }\end{array}$ & $\begin{array}{l}\text { Students immersed themselves in applied research } \\
\text { focused on the social, economic, and political context } \\
\text { and experiences of "workers and learners," or those } \\
\text { who work and attend college in Los Angeles County. } \\
\text { Students learned to conduct surveys, analyze data, and } \\
\text { contribute their analysis to a research brief. }\end{array}$ & $\begin{array}{l}\text { Summer 2018, 2019, } \\
2020\end{array}$ & 88 \\
\hline $\begin{array}{l}\text { LA County Colleges and } \\
\text { Universities Partnership }\end{array}$ & $\begin{array}{l}\text { Worker and learner surveyors trained students by } \\
\text { attending community college and CSU classes; two } \\
\text { separate sessions for each class. The first training } \\
\text { session focused on learning about the survey project } \\
\text { and practicing how to conduct the survey and how to } \\
\text { enter their survey results in a Qualtrics spreadsheet. } \\
\text { The second class reviewed survey results in a } \\
\text { participatory gallery walk and small group format to } \\
\text { discuss and critique their data. These trainings were } \\
\text { formally incorporated in the courses of faculty taught } \\
\text { across the California Community Colleges and } \\
\text { California State Universities. }\end{array}$ & $\begin{array}{l}\text { Academic Year } \\
2018-2019 \\
\text { Spring } 2020\end{array}$ & 467 \\
\hline
\end{tabular}

Analyzing quantitative data has involved various key activities, leading to insightful conversations about the various factors impacting a worker and learner's working, schooling, and personal experiences. Because faculty members taught their courses over a 10- or 
16-week period, we were limited on time; thus, to train students in data analysis, our UCLA student trainers returned to the classroom soon after students finished data collection. To guide our conversations with students, our student trainers held data analysis workshops with their undergraduate peers at the Los Angeles County California State Universities and the California Community College classes. In these data analysis workshops, students learned about the data analysis process, engaged in critical discussions about preliminary findings, and provided nuanced perspectives to help elucidate the data. We began reviewing data by compiling the initial frequencies from Qualtrics into a presentation on Google Slides. We created a worksheet that tasked students to reflect on those data points. Because we visited classrooms throughout the year, we were able to present on the most up-to-date frequencies in the analysis workshops. Furthermore, to ensure that all students had an opportunity to speak on the issues confronting workers and learners, students reviewed the findings for each core survey section (e.g., finances, college and work experience connections, work life, school life) in small-group discussions. Together, they reflected on the following questions:

1. What data points confirm or contradict what you know about workers and learners?

2. What data points are powerful? Why?

3. What problem(s) does that data point highlight? What could be some solutions?

4. Any other thoughts/reflections?

This data review ensured that all students across campuses who had collected data firsthand had the opportunity to share their reflections on the data results, and thus be a part of the broader conversation about worker and learner experiences. Like these inclassroom reflections, our UCLA student trainers produced reflection memos, an important step in the RJ approach for enacting change (Darder 2015). Securing opportunities for students to work together to discuss and analyze the data collaboratively has been a major component of working with our faculty partners across Los Angeles.

Having finished these data analysis workshops at the end of the 2018-2019 academic year, we engaged in "deep dives" with undergraduate students in the 2019 Labor Summer Research Program (LRSP) summer program. These focused sessions had students unpack the survey data and findings and decide what areas they would like to learn more about through further research. These "deep dives" were possible only after Ángeles, Wong, and a group of undergraduate students had cleaned the survey data in SPSS, a statistics software package. With the students, we were able to explore what the survey data looked like, how the data were organized in the program, and key statistical concepts that would allow them to guide their own analysis. This process resembles what Torre et al. (2012) has described as "Stats-n-Action," a way to engage student researchers in quantitative analysis by running analysis in real time with academics and analyzing the statistical output together to generate greater familiarity and understanding of the data (Torre et al. 2012).

Students not only analyzed data with each other in the classroom environment, but also, on several occasions, involved community stakeholders including student peers, faculty, and community organizers. Building on the data analysis workshops, students hosted several data gallery walks. In some participatory research conversations, these data gallery walks are known as data equity walks, a more active mode of exploring "the data individually before collectively discussing implications and identifying solutions to address disparities and improve outcomes" (The Education Trust-West 2016). All data gallery walks took place in community settings and were facilitated entirely by the students. The audience for the first data gallery walk were students. These events also featured music, games, and small group dialogue to discuss data points and worker and learner issues. The second event targeted faculty and other community stakeholders. Students created different stations to reflect emerging themes from the research findings. At each station, students presented four posters that included two to three visual graphics. Each station had one to two notetakers and one to two facilitators to guide the discussion around the data that community stakeholders and faculty highlighted using red stickers to indicate 
data points that they thought either confirmed or contradicted what they knew about workers and learners and blue stickers to highlight the data points they found powerful. They were also given "Solutions and Strategies" handouts on which participants could take note of the problems that the data highlighted, and provide solutions that were geared toward practice, policy, and cultural transformation. This event was also replicated with more than 100 community college students at Pierce Community College. These were powerful experiences in which undergraduate students from different college systems came together to engage in collective dialogue and make sense of the emergent findings. These community presentations demonstrated what Keer and Bussmann (2019) have underscored as the value of public thinkers and activists - seeing their expertise as being on par with that of scholars and academics. The gallery walks showcased the student's intellectual authority beyond academic ability, to include "spiritual, communal, cultural and lived experiences as forms of expertise" (Bay 2019, p. 13), thus allowing them to reclaim various forms of knowledge and to use the information to create change that is consistent with their values and needs (Kim Lee 2015).

Workers and learners also informed analysis of qualitative data. Since spring 2019 was spent analyzing quantitative data, LSRP students were invited to enroll in the UCLA Labor Summer Research Program in which they would learn to analyze interview data. The course covered a range of topics including coding, writing analytical memos (Saldaña 2016), crafting policy recommendations (Koonse 2019), and visualizing qualitative data (Hooper n.d.). Students also received training on how to use Dedoose, an analysis software for coding and conducting more refined code analysis of patterns. Initial discussions centered around whether they felt the codebook captured the varying aspects of the worker and learner experience as it related to labor conditions, academic experiences, and socioemotional needs (Saldaña 2016). After discussing the addition of new codes, students began to craft research questions that the data might help answer. This process led to the composition of a research memo for which students in the class, who again were workers and learners, reflected on the worker and learner experience. Orlando Fals Borda has posited that scholars need such deep, participatory reflections to achieve Research Justice (McTaggart 1994).

While the research memo was an individual activity, it was informed by the prior many discussions among students. This collaborative space of exchange resembles what Fine and Torre (2019) have described as participatory contact zones, spaces where very differently positioned people come together-across power, privilege, and vulnerabilities-to develop theoretical and methodological designs that focus on structural dynamics, engage history and contemporary social movements, and assume lives are simultaneously filled with pain, joy, and resistance (p. 434).

The range of discussions held also allowed students to identify recommendations they would make based on the survey and interview data. They were able to not only "critically examine what is" but also collaboratively "imagine what could be" (Fine and Torre 2019, p. 436). Though making recommendations serves the practical purpose of identifying possible solutions to pressing problems, the recommendations that the workers and learners highlighted in their memos were based upon the "magic wand" question-a question in both the survey and the interview - which queried students about the one thing they would change regarding their current working and academic experiences. "Magic wand" responses informed the discussions workers and learners had regarding policy recommendations, giving us the opportunity to "imagine the world beyond our current social and material conditions" (Darder 2015, p. 23). Our reports' recommendations were informed by the reimaginings of over 700 workers and learners about "what might be" for workers and learners at their workplaces as well as their colleges (Darder 2015, p. 23).

\subsection{Workers and Learners Disseminating Findings}

Involving undergraduate students throughout our analysis process was crucial to informing the three reports we have written and published thus far (Ángeles et al. 2020a, 
2020b; Labor Summer Research Program 2020 Team 2020). However, their contribution did not stop there. Adopting the tenets outlined by critical scholars like Michelle Fine, Andrew J. Jolivétte, and Cynthia Gordon da Cruz, the UCLA Labor Center has assumed the role of securing and utilizing institutional resources to facilitate opportunities so that our undergraduates can tell their stories about being a worker and learner utilizing the data they helped collect. This type of resource brokering upholds the last principle of RJ, which calls upon researchers to afford community members "control over all stages of the 'knowledge lifecycle'-from producing, analyzing, interpreting, packaging, and deploying knowledge" (Kim Lee 2015, p. xviii). Utilizing institutional resources allowed workers and learners the opportunity to directly communicate the report findings and share their lived experiences with a larger, more public audience (Lykes and Hershberg 2012). We highlight three different ways that we have involved undergraduate students in research dissemination, the final phase of the research process.

As we concluded the writing process, the research team collectively planned dissemination and media outreach strategies with workers and learners who had been participating in the project since summer 2019. As a research team, we discussed the importance of having workers and learners represent each segment of the three public college systems in Los Angeles County. Each public college system was represented by at least three undergraduate students. Initially our goal had been to do a press release at a local community college, but COVID-19 led us to move the event online. In planning for our press release, we realized that not all of our workers and learners had prior experience speaking as a representative on behalf of a cause and/or with the media as a spokesperson (California Immigrant Policy Center 2019; The Center for Media Justice 2009). We worked with the UCLA Institute for Research and Labor Employment's communications team to provide spokesperson training sessions and resources to support our workers and learners as they prepared to highlight how the reports' various findings resonated with their lived experiences. In our training, we highlighted that they were intimately knowledgeable with the research study-having been involved throughout the research process-but, most importantly, having lived the plight of workers and learners. As these workers and learners came together, representing different lived experiences, they embodied the "sacredness [that] comes from putting the pieces of knowledge together collectively; that makes that knowledge sacred is not that a few people know it, but that it is known by many" (Smith 2015, p. 208).

Following the online press release, blog posts were published to reach a more public audience. While Ángeles published a blog post speaking to our studies' findings and recommendations (Ángeles et al. 2020), a student researcher, Ayala, wrote another blog post highlighting the different ways in which the report findings reflected her lived experiences as a worker and learner (Ayala 2020). She composed this blog with the assistance of Shadduck-Hernández and the communications team, which helped secure a platform for her to publish her piece. Together, the communications and research team supported workers and learners like her in disseminating their accumulated knowledge (Smith 2015) to a larger public audience. Throughout our spokesperson training, we emphasized their individual and collective power as workers and learners in "creating, owning, and wielding information to affect change in their communities and lives" (Keer and Bussmann 2019, p. 15).

Among the most powerful activities the research team has facilitated have been the various Worker and Learner Summits, held since the release of our reports. These summits have centered around workers and learners utilizing the report findings to mobilize for change (Jolivétte 2015; Torre et al. 2012). Torre et al. (2012) suggested that the following actions can emerge from the research process: (a) building theory, (b) contributing to social policy, (c) performing data, and (d) distributing evidence to organizing allies. Similarly, Jolivétte and colleagues (2015) argued that RJ is a "movement-building strategy" encompassing "(1) strategies for knowledge construction and self-determination; (2) strategies for community mobilization; and (3) strategies for social transformation and policy reform" 
(p. 6). In order to bring the reports' findings to important stakeholders, workers and learners have organized various summits in which they not only present report findings to college faculty, administrators, and university staff, but then invite them to commit to taking concrete actions to make educational spaces more welcoming and attentive to the needs of workers and learners. This is the ultimate goal of involving participants in the research process-equipping and empowering them to take part in the "process of knowledge production about their lives ... and social conditions" (Salomón 2015, p. 190) as workers and learners-so as to effect change in the larger sociopolitical context (Oparah et al. 2015). This is research justice in action.

\section{Conclusions}

This article highlights how a university research project about the work and educational experiences of undergraduate students applied the tenets of PAR and RJ to build partner capacity, produce knowledge, involve participants in the knowledge lifecycle, and impact labor and higher education policy. Like other critical community engaged scholarship practitioners (Gordon da Cruz 2017), we were intentional about our research design and prioritized collaborating with and engaging faculty and students across multiple disciplines in all aspects of the research process to collectively improve conditions for workers and learners in their workplaces and postsecondary institutions.

Our goal was to showcase the various ways in which we designed our research activities and classrooms to "empower participants [while] recogniz[ing] their experiences as forms of knowledge making that we need in our research" (Bay 2019, p. 13). Our findings indicate that, with proactive research planning, design, and faculty collaboration, undergraduate students - with appropriate training in their college courses — can successfully become researchers and advocates in examining problems that impact them and their communities. This paper demonstrates how undergraduate students were integrated from the outset in the development of the research design, crafting of inquiry questions, piloting, amending, and applying research instruments, training other college students to become surveyors, analyzing the data, writing memos for the final report, and creating media materials and dissemination strategies and events to share the research results.

While this paper focuses on the strengths and benefits of PAR and RJ approaches in the Workers and Learners Project, a few limitations should be addressed. Given the scale at which this project operated (i.e., the training and inclusion of workers and learners at the UCs, Cal State, and California Community Colleges across LA county), it was a challenge to ensure equal representation at all stages of the project. Because the project was initiated and housed at the UCLA Labor Center with significant UCLA Labor Studies student participation in the development phases as well as throughout the life of the project certain aspects of Cal States and Community Colleges students' experiences were not highlighted, for example, in the survey instrument (e.g., different reasons for choosing a community college beyond gaining credentials needed to transfer to a 4-year program). Subsequent worker and learner studies should integrate undergraduate students from across the three public higher education systems with adequate access to funding and resources to include students across campuses in all phases of the research, particularly in the survey and interview protocol design. At the time of our study, our partner community college and Cal State systems did not have equal access to resources and research funds which can impact data collection and analysis. While the research team offered comprehensive training in survey data collection and analysis to students through their Cal State and Community Colleges classes, researchers did not have as much control over survey administration and the number of completed surveys. As a result, data collection and analysis could be compromised. Larger institutions (e.g., UCs) with access to resources and infrastructure, should consider expanding research partnerships with Cal States and Community Colleges to support their faculty and workers and learners in the development of sustainable PAR and RJ research agendas. 
Despite these limitations, this project contributes to the ongoing conversation about what it means for research participants to "participate" in research studies informed by the epistemology of PAR coupled with RJ. This approach allows us to challenge the power dynamics through which knowledge is often produced (e.g., top down), moving towards "the creation and maintenance of equitable power relationships across researcher and nonresearcher" (Asad 2019, p. 3), ultimately producing information that can help workers and learners advocate for their needs. While the current project may have benefited from other qualitative methods, such as structured interviews or case studies, providing a more in-depth understanding of the worker and learner experience, the PAR and RJ approach allowed for broader access to a more diverse sample of workers and learners from LA County. This approach provides an important snapshot of the various needs of workers and learners across different school systems in California to demonstrate the shared challenges they face as workers and learners in managing the demands of school and work. For example, data from this project highlighted pressing financial needs that are often obscured by the narrative of the traditional college student who is viewed as a full-time student with no major life or work responsibilities. However, this is far from the reality of workers and learners, many of whom must work to pay for basic household expenses, followed by their college expenses. Further, the data helped generate key recommendations to inform policies and institutions, such as providing tools for students and families to navigate financial systems, expanding work-study opportunities, and finding ways to make college affordable for all (Ángeles et al. 2020). By utilizing RJ to inform our research design and process, we are able to address the shortcomings of PAR-informed inquiry projects that do not address how to intentionally involve participants in the research process, which is necessary to "develop critically conscious knowledge, dismantle structural inequity, and make society more socially and racially just" (Gordon da Cruz 2017, p. 376).

We invite researchers to consider the ways that they are collaborating and leveraging the skills and expertise of the participants with whom they engage in community-engaged scholarship. It is our hope that others will find the Research Justice framework as helpful as we have found it as we strive to not only expand access to research opportunities for students attending postsecondary institutions, but also engage in a research process that actively incorporates the insights of students from the onset (Gordon da Cruz 2017). Without the support of our research partners, revealing the labor violations, scheduling inequities and workplace conditions that workers and learners face in their everyday lives would not have been possible. Only by inviting those most affected by these unjust labor practices (Ben-Ishai et al. 2016; Flaherty 2019; Jacobs and Thomason 2018) and educational structures (Ángeles et al. 2020a; Carnevale et al. 2015; Carnevale and Smith 2018) can we identify and reimagine the "policies, institutions, and social arrangements that help to form and deform, enrich and limit" (Torre et al. 2012, p. 179) workers and learners' ability to thrive and succeed.

Author Contributions: Conceptualization, S.L.Á. and P.S.; methodology, S.L.Á. and M.J.W.; writingoriginal draft preparation, S.L.Á. and M.J.W.; writing-review and editing, S.L.Á., M.J.W., J.S.-H., and P.S. All authors have read and agreed to the published version of the manuscript.

Funding: This research was funded by the UCLA Institute for Research on Labor and EmploymentLabor Studies Program during the Labor Studies Summer Research Program (2019-2020).

Institutional Review Board Statement: The study was conducted according to the guidelines of the Declaration of Helsinki, and approved by the Institutional Review Board of the University of California, Los Angeles (IRB_19-001287 approved on January 9, 2019; IRB_ 20-000694 approved on April 17, 2020; IRB_20-001385 approved on 24 July 2020).

Informed Consent Statement: Informed consent was obtained from all subjects involved in the study.

Acknowledgments: We thank our larger UCLA Labor Center and Dolores Huerta Labor InstituteLos Angeles Community College District Workers and Learners research team (Mindy Chen, Jenny 
Galvez, Deja Thomas, and Saba Waheed) for their encouragement in developing this paper. This paper is the result of the innovative research agenda carried out by this team over the past three years with undergraduate.

Conflicts of Interest: The authors declare no conflict of interest.

\section{References}

Adelman, Clem. 1993. Kurt Lewin and the origins of action research. Educational Action Research 1: 7-24. [CrossRef]

Allison, Juliann Allison, Tabassum “Rubi" Khan, Ellen Reese, Becca Spence Dobias, and Jason Struna. 2015. Lessons from the labor organizing community and health project: Meeting the challenges of student engagement in community based participatory research. Journal of Public Scholarship in Higher Education 5: 5-30.

Ángeles, Sophia L., Janna Shadduck-Hernández, and Saba Waheed. 2020. Workers and Learners' Experiences in Los Angeles County. LA Social Science. Available online: https:/ /lasocialscience.ucla.edu/2020/08/28/workers-and-learners-experiences-in-losangeles-county / (accessed on 29 December 2021).

Ángeles, Sophia. L., Mindy Chen, Jenny Galvez, Janna Shadduck-Hernández, Preeti Sharma, Deja Thomas, Saba Waheed, and Michele Wong. 2020a. A Survey of Workers and Learners in Los Angeles County during COVID-19. Los Angeles: UCLA Labor Center. Available online: https: / / www.labor.ucla.edu/publication/a-survey-of-workers-and-learners-in-los-angeles-county-during-covid-19/ (accessed on 29 December 2021).

Ángeles, Sophia L., Mindy Chen, Jenny Galvez, Janna Shadduck-Hernández, Preet Sharma, Deja Thomas, Saba Waheed, and Michele Wong. 2020b. Unseen Costs: The Experiences of Workers and Learners in Los Angeles County. Los Angeles: UCLA Labor Center. Available online: https:/ / www.labor.ucla.edu/wp-content/uploads/2020/06/UNSEEN-COSTS-6.22.2020.pdf (accessed on 29 December 2021).

Asad, M. 2019. Prefigurative design as a method for Research Justice. Proceedings of the ACM on Human-Computer Interaction 3: 1-18. [CrossRef]

Ayala, Lesly. 2020. Students and COVID-19: We Are Struggling, Here's the Help We Need. Medium. Available online: https: / / uclalaborcenter.medium.com/students-and-covid-19-we-are-struggling-heres-the-help-we-need-d354831018dc (accessed on 29 December 2021).

Bay, Jennifer L. 2019. Research Justice as reciprocity: Homegrown research methodologies. Community Literacy Journal 14: 7-25. [CrossRef]

Ben-Ishai, Liz, Tia Koonse, Mitzi Marquez-Avila, Reyna Orellana, Jeylee Quiroz, Janna Shadduck-Hernández, and Saba Waheed. 2016. Juggling Time: \#Young Workers and Scheduling Practices in the Los Angeles County Service Sector. Los Angeles: UCLA Labor Center. Available online: https://www.labor.ucla.edu/wp-content/uploads/2018/06/UCLA_YoungWorkerScheduling_proof3.pdf (accessed on 29 December 2021).

Bertrand, Melanie. 2018. Youth Participatory Action Research and possibilities for students of color in educational leadership. Educational Administration Quarterly 54: 366-95. [CrossRef]

Blanchard Kyte, Sarah. 2017. Who Does Work Work for? Understanding Equity in Working Learner College and Career Success. Iowa City: ACT's Center for Equity in Learning. Available online: http://equityinlearning.act.org/wp-content/uploads/2017/08/ WhoDoesWorkWorkFor.pdf (accessed on 29 December 2021).

Bozick, Robert. 2007. Making it through the first year of college: The role of students' economic resources, employment, and living arrangements. Sociology of Education 80: 261-84. [CrossRef]

Broton, Katharine M., and Sara Goldrick-Rab. 2018. Going without: An exploration of food and housing insecurity among undergraduates. Educational Researcher 47: 121-33. [CrossRef]

Broton, Katharine M., Sara Goldrick-Rab, and James Benson. 2016. Working for college: The causal impacts of financial grants on undergraduate employment. Educational Evaluation and Policy Analysis 38: 477-94. [CrossRef]

Burnham, Linda, and Nik Theodore. 2012. Home Economics: The Invisible and Unregulated World of Domestic Work. New York City: National Domestic Workers Alliance. Available online: https:/ /www.domesticworkers.org/wp-content/uploads/2021/06/ HomeEconomicsReport.pdf (accessed on 1 February 2022).

California Immigrant Policy Center. 2019. Transforming Our Narratives for a New Era: A Communications Toolbox for Immigrant Rights Advocates in California. Los Angeles: California Immigrant Policy Center. Available online: https://www.dropbox.com/sh/3b516 34jcjofr5n / AAAkJKE-rnD8xUu0Iq5qUj9Ia?dl=0\&preview=CIPC+Communications+Toolkit-ONLINE-FINAL.pdf (accessed on 29 December 2021).

Cammarota, Julio, and Michelle Fine. 2008. Revolutionizing Education: Youth Participatory Action Research in Motion. New York: Routledge.

Carnevale, Anthony P., and Nicole Smith. 2018. Balancing Work and Learning: Implications for Low-Income Students. Washington D.C.: Center on Education and the Workforce. Available online: https://1gyhoq479ufd3yna29x7ubjn-wpengine.netdna-ssl.com/wpcontent/uploads/Low-Income-Working-Learners-FR.pdf (accessed on 29 December 2021).

Carnevale, Anthony, Nicole Smith, Michelle Melton, and Eric W. Price. 2015. Learning While Earning: The New Normal. Washington D.C.: Center on Education and the Workforce. Available online: https://cew.georgetown.edu/wp-content/uploads/WorkingLearners-Report.pdf (accessed on 29 December 2021). 
Crutchfield, Rashida, Keesha Clark, Sara Gamez, Aaron Green, Deidre Munson, and Hanna Stribling. $2016 . \quad$ Serving Displaced and Food Insecure Students in the CSU. Long Beach: The California State University Office of the Chancellor. Available online: https://www.calstate.edu/impact-of-the-csu/student-success/basic-needs-initiative/Documents/ ServingDisplacedandFoodInsecureStudetnsintheCSUJanuary20163.8.16.pdf (accessed on 29 December 2021).

Darder, Antonia. 2015. Imagining justice: Politics, pedagogy, and dissent. In Research Justice: Methodologies for Social Change. Edited by Andrew J. Jolivétte. Great BritainGreat Britan: Policy Press, pp. 13-26.

Data Center: Research for Justice. 2013. An Introduction to Research Justice. Oakland: Data Center: Research for Justice. Available online: http:/ / www.datacenter.org/wp-content/uploads/Intro_Research_Justice_Toolkit_FINAL1.pdf (accessed on 29 December 2021).

Dick, Bob. 2015. Reflections on the SAGE encyclopedia of action research and what it says about action research and its methodologies. Action Research 13: 431-44. [CrossRef]

Dwyer, Richard. 1977. Workers' education, labor education, labor studies: An historical delineation. Review of Educational Research 47: 179-207. [CrossRef]

Ehrenberg, Ronald G., and Daniel R. Sherman. 1987. Employment while in college, academic achievement, and postcollege outcomes: A summary of results. The Journal of Human Resources 22: 1-23. [CrossRef]

Fine, Michelle, and Maria Elena Torre. 2019. Critical Participatory Action Research: A feminist project for validity and solidarity. Psychology of Women Quarterly 43: 433-44. [CrossRef]

Flaherty, Colleen. 2019. Ruling Out Grad Unions. Washington D.C.: Inside Higher Ed, September 23. Available online: https: //www.insidehighered.com/news/2019/09/23/trump-labor-board-proposes-new-rule-against-grad-unions (accessed on 29 December 2021).

Gaffney, Michael. 2008. Participatory Action Research: An overview. Kairaranga 9: 9-15.

Gordon da Cruz, Cynthia. 2017. Critical Community-Engaged Scholarship: Communities and universities striving for racial justice. Journal of Education 92: 363-84. [CrossRef]

Gutiérrez, José. 2016. Participatory Action Research (PAR) and the Colombian Peasant Reserve Zones: The legacy of Orlando Fals Borda. Policy and Practice: A Development Education Review 22: 59-76. Available online: https://www.developmenteducationreview. com/issue/issue-22/participatory-action-research-par-and-colombian-peasant-reserve-zones-legacy-orlando (accessed on 29 December 2021).

Hooper, Lydia. n.d. Using human-Centered Design to Visualize Qualitative Data: A Workbook. Available online: https://static1 .squarespace.com/static/553d1cdae4b0e618515f1037/t/5ce09a3c60b1030001e5a602/1558223422629/QualitativeDatavizWorkbook_ LydiaHooper.pdf (accessed on 29 December 2021).

Horn, Laura J., and Andrew G. Malizio. 1996. Undergraduates Who Work: National Postsecondary Student Aid Study; Washington, DC: National Center for Education Statistics. Available online: https://nces.ed.gov/pubs98/98137.pdf (accessed on 29 December 2021).

Jacobs, Ken, and Sarah Thomason. 2018. The Union Effect in California \#1: Wages, Benefits, and Use of Public Safety Net Programs. Berkeley: UC Berkeley Center for Labor Research and Education. Available online: https://laborcenter.berkeley.edu/pdf/2018/UnionEffect-in-California-1.pdf (accessed on 29 December 2021).

Jolivétte, Andrew. J. 2015. Research Justice: Methodologies for Social Change. Great Britain: Policy Press.

Keer, Gr, and Jeffra Diane Bussmann. 2019. A case for a critical information ethics: Lessons learned from Research Justice. Journal of Critical Library and Information Studies 2: 1-22. [CrossRef]

Kim Lee, Miho. 2015. Foreword. In Research Justice: Methodologies for Social Change. Edited by Andrew J. Jolivétte. Great Britain: Policy Press, pp. xvii-xx.

Kindon, Sara, Rachel Pain, and Mike Kesby, eds. 2007. Introduction: Connecting people, participation, and place. In Participatory Action Research Methods and Approaches: Connecting People, Participation, and Places. London: Routledge, pp. 1-6.

Koonse, Tia. 2019. How to conduct policy research. Lecture presented at Labor Summer Research Program 2019, Los Angeles, CA, August.

Labor Summer Research Program 2020 Team. 2020. Workers and Learners during a Global Pandemic and Social Movements. Los Angeles: UCLA Labor Center. Available online: https:/ / www.labor.ucla.edu/publication/lsrp/ (accessed on 1 February 2022).

Lykes, M. Brinton, and Rachel M Hershberg. 2012. Participatory action research and feminisms: Social inequalities and transformative praxis. In Handbook of Feminist Research: Theory and Praxis. Edited by Sharlene Nagy Hesse-Biber. Thousand Oaks: Sage Publishing, pp. 331-67.

Manzo, Peter, Henry Gascon, Betsy Baum Block, and Dan Beeby. 2021. Struggling to Move Up: The Real Cost Measure in California 2021. Available online: https:/ / www.unitedwaysca.org/images/RealCostMeasure2021/The-Real-Cost-Measure-in-California2021-Executive-Summary.pdf (accessed on 17 November 2021).

McTaggart, Robin. 1994. Participatory Action Research: Issues in theory and practice. Educational Action Research 2: 313-37. [CrossRef]

Oparah, Julia Chinyere, Fatimah Salahuddin, Ronnesha Cato, Linda Jones, Talita Oseguera, and Shanelle Matthews. 2015. By us, not for us: Black women researching pregnancy and childbirth. In Research Justice: Methodologies for Social Change. Edited by Andrew J. Jolivétte. Great Britain: Policy Press, pp. 117-37.

Perna, Laura W., and Chunyan Li. 2006. College affordability: Implications for college opportunity. Journal of Student Financial Aid 36: 1.

Raskind, Ilana G., Regine Haardörfer, and Carla J. Berg. 2019. Food insecurity, psychosocial health and academic performance among college and university students in Georgia, USA. Public Health Nutrition 22: 476-85. [CrossRef] 
Riggert, Steven C., Mike Boyle, Joseph M. Petrosko, Daniel Ash, and Carolyn Rude-Parkins. 2006. Student employment and higher education: Empiricism and contradiction. Review of Educational Research 76: 63-92. [CrossRef]

Robles Lomeli, Jafte Dilean, and Joanne Rappaport. 2018. Imagining Latin American social science from the Global South: Orlando Fals Borda and participatory action research. Latin American Research Review 53: 597-612. [CrossRef]

Saldaña, Johnny. 2016. The Coding Manual for Qualitative Researchers, 3rd ed. Thousand Oaks: Sage Publishing.

Salomón, Andrew J. 2015. Telling to reclaim, not to sell: Resistance narratives and the marketing of justice. In Research Justice: Methodologies for Social Change. Edited by Andrew J. Jolivétte. Great Britain: Policy Press, pp. 185-98.

Sandwick, Talia, Michelle Fine, Andrew Cory Greene, Brett G. Stoudt, Maria Elena Torre, and Leigh Patel. 2018. Promise and provocation: Humble Reflections on Critical Participatory Action Research for social policy. Urban Education 53: $473-502$. [CrossRef]

Shadduck-Hernández, Janna, Saba Waheed, Preeti Sharma, Lina Stepick, Vina Nguyen, Monica Macias, and Reyna Orellana. 2018. Hour Crisis: Unstable Schedule in the Los Angeles Retail Sector. UCLA Labor Center. Available online: https: / www.labor.ucla.edu/ wp-content/uploads/2018/06/FINAL_UCLA-Scheduling-Report-3-12-2018.pdf (accessed on 29 December 2021).

Sharma, Preeti, Janna Shadduck-Hernández, and Saba Waheed. 2020. I Am a \#Young Worker-Young Workers Animated for Change Workshop and Classroom Guide. Los Angeles: UCLA Labor Center. Available online: https://www.labor.ucla.edu/wp-content/ uploads/2020/03/Young-Worker-Curriculum-3.2020.pdf (accessed on 29 December 2021).

Smith, Linda Tuhiwai. 2015. Decolonizing knowledge: Toward a critical indigenous Research Justice praxis. In Research Justice: Methodologies for Social Change. Edited by A. J. Jolivétte. Great Britain: Policy Press, pp. 205-9.

Sukarieh, Mayssoun, and Stuart Tannock. 2015. The education penalty: Schooling, learning and the diminishment of wages, working conditions and worker power. British Journal of Sociology of Education 38: 254-64. [CrossRef]

Tanabe, Mihoko, Emma Pearce, and Sandra K. Krause. 2018. "Nothing about us, without us": Conducting participatory action research among and with persons with disabilities in humanitarian settings. Action Research 16: 280-98. [CrossRef]

Tannock, Stuart, and Sara Flocks. 2003. "I know what it's like to struggle": The working lives of young students in an urban community college. Labor Studies Journal 28: 1-30. [CrossRef]

The Center for Media Justice. 2009. Tips for a Spokesperson. Oakland, CA, USA: The Center for Media Justice. Available online: https://mediajustice.org/wp-content/uploads/2020/01/SpokespersonTipsHandout.pdf (accessed on 29 December 2021).

The Education Trust-West. 2016. Data Equity Walk Toolkit. Oakland: The Education Trust-West. Available online: https://west.edtrust. org/data-equity-walk-toolkit/ (accessed on 27 August 2021).

The Food Chain Workers Alliance. 2012. The Hands That Feed Us: Challenges and Opportunities for Workers along the Chain. Los Angeles: The Food Chain Workers Alliance. Available online: http:/ / www.datacenter.org/wp-content/uploads/Hands-That-Feed-UsReport.pdf (accessed on 27 August 2021).

Torre, Maria Elena, and Michelle Fine. 2006. Researching and resisting: Democratic policy research by and for youth. In Beyond Resistance! Youth Activism and Community Change: New Democratic Possibilities for Practice and Policy for America's Youth. Edited by Pedro Noguera and Julio Cammarota Shawn A. Ginwright. New York: Routledge, pp. 269-86.

Torre, Maria Elena, Michelle Fine, Brett G. Stoudt, and Madeline Fox. 2012. Critical participatory action research as public science. In APA Handbooks in Psychology ${ }^{\circledR}$. APA Handbook of Research Methods in Psychology, Vol. 2. Research Designs: Quantitative, Qualitative, Neuropsychological, and Biological. Edited by Harris Cooper, Paul M. Camic, Debra L. Long, A. T. Panter, David Rindskopf and Kenneth J. Sher. Washington, DC: American Psychological Association, pp. 171-84. [CrossRef]

UCLA Labor Center. 2019. Earners and Learners: Surveyor Training [PowerPoint Slides]. Los Angeles: UCLA Labor Center. Available online: https:/ / docs.google.com/presentation/d/1gf0FaRCB-qvWdQlHlfQLGZUPhIp-LdYEytAFKWRN-P0/edit\#slide=id. g4c15ada88f_0_7 (accessed on 29 December 2021).

Wadsworth, Yoland. 1998. What Is Participatory Action Research? Action Research International 2. Available online: https://www. montana.edu/cpa/news/images/articles/hires/img200603291143660763-1.pdf (accessed on 27 August 2021).

Waheed, Saba, Janna Shadduck-Hernández, Alfredo Alvarez, Mohammad Khairul Amin, Diana Campos-Valenzuela, Mark Anthony Franco, Enedina Geraldo, Lucero Herrera, Yanely Marin, Reyna Gabriela Orellana, and et al. 2015. I Am a \#Youngworker: Restaurant and Retail Workers in Los Angeles. Available online: https://www.labor.ucla.edu/wp-content/uploads/2018/06/ UCLA_youngworker_8.pdf (accessed on 29 December 2021).

What Kids Can Do. n.d. Recognizing the Knowledge of Young People: An Interview with Michelle Fine and Maria Elena Torre on Youth Action Research. Available online: http://www.whatkidscando.org/featurestories/previous_years/color_of_learning/ interview.html (accessed on 27 August 2021).

Zeller-Berckman, Sarah M. 2014. Lineages: A past, present, and future of participatory action research. In The Oxford Handbook of Qualitative Research. Edited by Patricia Leavy. Oxford: Oxford University Press, pp. 518-32. [CrossRef] 